\title{
PERANAN KEPEMIMPINAN KEPALA DESA TERHADAP PENYELESAIAN KONFLIK SENGKETA TANAH DI DESA CEMBA KECAMATAN ENREKANG
}

\author{
Irfan Nopandi Ismail, Muhammad Rais Rahmat Razak \\ IImu Pemerintahan, Fakultas IImu Sosial dan IImu Politik Universitas Muhammadiyah Sidenreng Rappang \\ Irfannopandi10@gmail.com; mraisrahmat@umsrappang.ac.id
}

\begin{abstract}
Abstrak
Tujuan penelitian ini yaitu untuk mengetahui peranan kepemimpinan kepala desa terhadap penyelesaian konflik sengketa tanah di Desa Cemba Kecematan Enrekang Kabupaten Enrekang. Jenis dan Tipe Penelitian ini menggunakan Deskriptif Kuantitatif, Populasi dalam penelitian ini seluruh masyarakat Desa Cemba sebanyak 1.875 orang, dan Sampel penelitian ini sebanyak 95 orang. Teknik pengumpulan data yang dilakukan dalam penelitian ini adalah dengan menggunakan teknik (1) Obsevasi, (2) Kuisioner, (3) Studi Kepustakaan. Data yang tekumpul kemudian dianalisis dengan menggunakan tabel frekuensi dengan menggunakan skala Likert dan dengan bantuan SPSS. Hasil penelitian ini menunjukkan bahwa peranan kepemimpinan Kepala Desa di Desa Cemba sebesar 48,4\% atau dikategorikan Cukup Baik, cara penyelesaian konflik sengketa tanah di Desa Cemba sebesar 44,34\% atau dikategorikan Cukup Baik, dan berdasarkan hasil penelitian dapat disimpulkan dari hasil tabel summary bahwa terdapat pengaruh yang signifikan antara peranan kepemimpinan Kepala Desa terhadap penyelesaian konflik sengketa tanah sebesar 49,7\% atau dikategorikan Cukup Baik.
\end{abstract}

Kata Kunci: Peranan Kepemimpinan, Cara menyelesaikan konflik

\begin{abstract}
The purpose of this study was to determine the role of the village head's leadership in resolving the tana dispute conflict in Cemba village, Kec. Enrekang, Enrekang district. The type and type of this study used descriptive quantitative, the population in this study were all Cemba villagers as many as 1,875 people, and the sample of this study was 95 people. Data collection techniques carried out in this study were using techniques (1) observation, (2) questionnaires, (3) literature study. The collected data were then analyzed using frequency tables using a Likert scale and with the help of SPSS. The results of this study indicate that the leadership role of the Village Head in Cemba Village is $48.4 \%$ or categorized as Good enough, the way the land dispute conflict resolution in Cemba Village is $44.34 \%$ or categorized as Good enough, and based on research results can be concluded from the summary table results that there is a significant influence between the role of leadership of the Village Chief in resolving land dispute conflicts of $49.7 \%$ or categorized as Good enough.
\end{abstract}

Keywords: Role of Leadership, How to resolve conflict

PRAJA| Volume 8| Nomor 1| Edisi Februari 2020 


\section{A. PENDAHULUAN}

Sebagian besar penduduk indonesia bermata pencarian sebagai petani. Tingkat ketergantungan akan ketersediaan tanah bagi kelangsungan hidupnya sangat tinggi. Di satu sisi persediaan tanah terbatas karena tidak dapat digandakan, sedangkan di sisi lain tingkat pertumbuhan penduduk tidak dibendung yang mengakibatkan meningkatnya kebutuhan akan tanah. Hal tersebut mengakibat akan terjadi ketidak seimbangan antara ketersediaan dan permintaan akan tanah. Hal ini mendorong setiap orang atau anggota masyarakat untuk mempertahankan tanah yang telah menjadi miliknya atau menganggap sebagai yang berhak atas tanah tersebut dari setiap upaya pihak lain yang ini menguasainya.

Konflik dan pertentangan memang tidak bisa dihindarkan dalam diri manusia baik sebagai makhluk pribadi terlebih sebagai makhluk sosial. Masyarakat desa dikenal dengan adanya perbedaan sosial, perbedaan sosial tersebut bisa meliput : perbedaan ekonomi, politik, pendidikan, agama dan lainlain. Perbedaan politik dan ekonomi merupakan sesuatu yang menyebabkan adanya konflik antar sesama individu dan kelompok. Oleh karena itu, dalam menangani konflik antara masyarakat khususnya dipedesaan maka sangat dibutuhkan motivator, fasilitator, dan mediator dalam hal ini adalah kepala desa selaku pemimpin dalam suatu desa. Kepala Desa adalah wakil Desa yang ditunjuk secara formal dan dipercaya oleh pemerintah serta masyarakat desa untuk menjalankan tugas maupun fungsinya sebagai pucuk pimpinan organisasi pemerintahan desa.Seperti yang ditemukan di Desa Cemba Kecamatan Enrekang Kabupaten Enrekang, berdasarkan hasil observasi yang pada tanggal 10 February 2019 diperoleh data dari petugas pencatatan laporan atas nama Rahmawati, bahwa di desa Cemba sering terjadi kasus sengketa tanah. Terbukti dalam tahun 2014 telah terjadi kasus sengketa tanah sebanyak tiga kasus.

Salah satu kasus sengketa tanah tersebut tidak dapat di selesaikan dalam lingkup pemerintahan desa Cemba dan diserahkan untuk dibahas selanjutnya di tingkat kecematan karena tidak ditemukannya kesepekatan antara kedua belah pihak.
Berdasarkan data diatas, maka penulis merasa tertarik untuk melakukan penelitian tentang "Peranan kepemimpinan kepala desa terhadap penyelesaian konflik sengketa tanah di Desa Cemba Kecamatan Enrekang Kabupaten Enrekang "dengan tujuan Untuk mengetahui peranan kepemimpinan kepala desa di Desa Cemba Kecamatan Enrekang Kabupaten Enrekang, Untuk mengetahui konflik sengketa tanah di Desa Cemba Kecamatan Enrekang Kabupaten Enrekang, dan Untuk mengetahui peranan dan kepemimpinan kepala desa terhadap penyelesaikan konflik sengketa tanah di Desa Cemba Kecamatan Enrekang Kabupaten Enrekang

\section{Peranan}

Menurut Kamus Besar Bahasa Indonesia, peran didefenisikan sebagai seperangkat tingkat yang diharapkan dimiliki oleh orang yang berkedudukan dalam masyarakat. Menurut(Soekanto, 2002) Peranan adalah pertama, merupakan aspek dinamis kedudukan apabila seseorang melaksanakan hak dan kewajiban sesuai dengan kedudukannya dia menjalankan suatu peranan. Kedua, peranan adalah karena ia mengatur perilaku seseorang dan peranan menyebabkan seseorang pada batas tertentu dapat meramalkan perbuatanperbuatan orang lain, ketiga, peranan adalah diatur norma-norma yang berlaku misalnya norma kesopanan menghendaki seseorang laki-laki bila berjalan bersama seorang wanita, harus disebelah luar. Peranan adalah sesuatu yang menjadi bagian yang memegang pimpinan yang terutama dalam terjadinya suatu hal atau peristiwa. Secara ringkas dapat dikatakan bahwa semakin tinggi kedudukan seseorang dalam suatu hierarki organisasi, semakin sedikit keterampilan teknis yang diperlukan. Sebaliknya, semakin rendah kedudukan seseorang dalam suatu hierarki organisasi, semakin penting keterampilan teknis yang diperlukan, (Siswanto, 2012).Menurut(Soekanto, 2012)menjelaskan pengertian peranan merupakan aspek dinamis kedudukan (status). Apabila seseorang melakukan hak dan kewajibannya sesuai dengan kedudukannya, dia menjalankan suatu peranan. Perbedaan antara kedudukan dan peranan adalah untuk kepentingan ilmu pengetahuan. Keduanya tak dapat dipisah-pisahkan karena yang satu 
tergantung pada yang lain dan sebaliknya. Tak ada peranan tanpa kedudukan atau kedudukan tanpa peranan. Sebagaimana dengan kedudukan, peranan juga mempunyai dua arti. Setiap orang mempunyai macam-macam peranan yang berasal dari pola-pola pergaulan hidupnya. $\mathrm{Hal}$ itu sekaligus berarti bahwa peranan menentukan apa yang diperbuatnya bagi masyarakat serta kesempatan-kesempatan apa yang diberikan oleh masyarakat kepadanya.

$$
\text { Peranan kepala desa dalam }
$$
menyelesaikan konflik antar warga menurut(Nordholt, Schute dan Klinken, Van, 2007) dengan indikator sebagai berikut:

a. Peranan sebagai motivator yaitu peran kepala desa sebagai pendorong dan pemberi semangat kepada masyarakat setempat, agar tidak melakukan tindakantindakan yang positif sehingga apa yang diharapkan adapat lebih berkembang dan terjaminnya stabilitas keamanan dan ketertiban masyarakat, suatu saat dapat menjadi penopang perekonomian yang ada.

b. Peran sebagai fasilitator dalam ini kepala desa sebagai orang yang memberikan bantuan dan menjadi narasumber yang baik untuk berbagi permasalahan serta menfasilitasi kegiatan-kegiatan di desa.

c. Peran sebagai mediator kepala desa menjadi penengah/penetralisir antar warga yang saling berkonflik dan mempertemukan satu dengan yang lainnya, sehingga kata sepakat dan perdamaian dapat terjalin.

\section{Kepemimpinan}

Kepemimpinan berasal dari kata pimpin yang memuat dua hal pokok yaitu: pemimpin sebagai subjek dan yang dipimpin sebagai objek. Kata pimpin mengandung pengertian mengarahkan, membinaatau mengatur, menuntun dan juga menunjukkan atapun mempengaruhi. Menurut (Kartono Kartini, 2014)bahwa pemimpin adalah seseorang pribadi yang memiliki kecakapankecakapan dan kelebihan-kelebihan. Kecakapan dan kelebihan ini yang dimaksudkan agar pemimpin itu mampu mempengaruhi orang lain untuk bersamasama melakukan aktivitas tertentu demi pencapaian tujuan.Menurut(Rivai, 2012)Kepemimpinan adalah seorang pemimpin dalam proses mengarahkan dan mempengaruhi aktivitas-aktivitas yang ada hubungannya dengan pekerjaan para anggota kelompok."Gaya kepemimpinan merupakan norma perilaku yang digunakan oleh seseorang pada saat mencoba mempengaruhi perilaku orang lain" (Thoha., 2004).Ada beberapa macam gaya kepemimpinan menurut (Robbins, 2006) , yaitu:

\section{a. Kepemimpinan Kharismatik}

Kepemimpian yang membuat para pengikut terpicu oleh kemampuan pemimpin yang heroik atau luar biasa ketika mereka mengamati perilaku tertentu pemimpin. Pemimpin kharismatik dapat mempengaruhi para pengikut mereka dengan cara mengutarakan jelas visi yang menarik, visi ini berhubungan antara masa kini dengan masa depan sehingga karyawan tertarik untuk mengikutinya, kemudian pemimpin mengkomunikasikan harapan akan kinerja yang tinggi dan menyatakan bahwa karyawan dapat mencapai kinerja tersebut dengan baik, hal tersebut membuat para karyawan semakin percaya diri dan harga dirinya naik, kemudian pemimpin mengungkapkan katakata dan tindakan yang penuh dengan nilainilai, selain itu pemimpin memberikan contoh perilaku baik agar karyawan dapat meniru.

\section{b. Kepemimpinan Transformasional}

Gaya kepemimpinan transformasional yakni pemimpin yang menginspirasi pengikut untuk melakukan hal yang melebihi kepentingan pribadi mereka demi kepentingan perusahaan dan mampu memberikan dampak mendalam dan luar biasa kepada para karyawan. Kepemimpinan transformasioanl dapat mengubah pola pikir karyawan dari pola pikir yang menyelesaikan masalah dengan cara lama diubah menjadi penyelesaian masalah dengan cara baru yang lebih baik, selain itu pemimpin transformasional mampu membuat karyawan bergairah dalam bekerja, membangkitkan semangat dan membuat karyawan melakukan upaya ekstra untuk mencapai tujuan perusahaan. Kepemimpinan transformasional ada sebagai tambahan kepemimpinan transaksional, kepemimpinan ini dapat menghasilkan tingkat kinerja lebih baik, memiliki sifat lebih dari kharisma, memberikan visi dan misi, menanamkan kebanggaan, mengkomunikasikan agar harapan menjadi tinggi, berfokus pada usaha 
serta menggambarkan maksud penting secara sederhana.

\section{c. Kepemimpinan Transaksional}

Pemimpin yang memotivasi pengikut mereka untuk menuju kesasaran yang ditetapkan dengan memeperjelas persyaratan dan tugas. Pemimpin transaksional memeliki karakter tersendiri yaitu imbalan kontingen yang menjanjikan imbalan untuk kinerja yang baik dan pemimpin mengakui pencapaian yang diraih karyawan, kemudian menempuh tindakan perbaikan, dan menghindari adanya pembuatan keputusan yang akan diambil.

\section{d. Kepemimpinan Visioner}

Kemampuan menciptakan dan mengartikulasikan visi yang realistis, kredibel dan menarik mengenai masa depan organisasi atau unit oganisasi yang telah tumbuh dan membaik dibanding saat ini. Visi dapat menjadikan sebuah lompatan besar ke masa depan dengan cara membangkitkan ketrampilan, bakat dan sumberdaya. Visi memberikan gairah yang baru mengenai masa depan yang lebih baik, memberikan inspirsi, dapat memberikan komitmen ke tempat kerja dan dapat menghasilkan kualitas organisasi yang lebih unggul. Kepemimpinan visioner memiliki cara dan kualitas tersendiri dalam melakukan pekerjaanya, yaitu pemimpin memiliki kemampuan menjelaskan visi keorang lain, kemudian dapat mengukapkan visi dengan perilaku tidak hanya secara verbal, dan memiliki kemampuan memperluas visi keberbagai konteks kepemimpinan yang berbeda.

\section{Peranan Kepala Desa menyelesaikan Konflik SengketaTanah}

Peran kepala desa dalam menyelesaikan konflik antar warga desa masih dirasakan belum maksimal.Untuk dapat mengatasi konflik-konflik yang ada dimasyarakat desa, kepala desa harus melakukan mediasi dengan memberikan kesempatan kepada semua anggota kelompok untuk mengemukakan pendapatnya tentang kondisi-kondisi penting yang diinginkan, yang menurut persepsi masing-masing harus dipenuhidengan pemanfaatan berbagai sumber daya dan dana yang tersedia. Meminta satu pihak menempatkan diri pada posisi orang lain, dan memberikan argumentasi kuat mengenai posisi tersebut. Kemudian posisi peran itu dibalik, pihak yang tadinya mengajukan argumentasi yang mendukung suatu gagasan seolah-olah menentangnya, dan sebaliknya pihak yang tadinya menentang satu gagasan seolah- olah mendukungnya. Setelah itu tiaptiap pihak diberi kesempatan untuk melihat posisi orang lain dari sudut pandang pihak lain.Nader dan Todd mengemukakan tujuh cara penyelesaian sengketa. Ketujuh cara tersebut disajikan berikut ini :

a. Membiarkan saja atau lumping it. Pihak yang merasakan perlakuan yang tidak adil, gagal dalam upaya untuk menekankan tuntutannya dia mengambil keputusan untuk mengabaikan saja masalah atau isu yang menimbulkan tuntutannya dan dia meneruskan hubungan-hubungannya dengan pihak yang dirasakan merugikannya. Ini dilakukan karena berbagai kemungkinan seperti kurangnya faktor informasi mengenai bagaimana proses mengajukan keluhan itu ke peradilan; kurangnya akses ke lembaga peradilan karena diperkirakan bahwa kerugiannya lebih besar dari keuntungannya.

b. Mengelak (avoidance). Pihak yang merasa dirugikan memilih untuk mengurangi hubungan-hubungan dengan pihak yang merugikan-nya atau untuk sama sekali menghentikan hubungan tersebut. Misalnya, dalam hubungan bisnis, hal semacam ini bisa terjadi. Dengan mengelak, isu yang menimbulkan keluhan dielakkan saja.Berbeda dengan pemecahan pertama, di mana hubunganhubungan berlangsung terus, isunya saja yang dianggap selesai. Dalam hal bentuk kedua ini, pihak yang dirugikan mengelakkannya. Pada bentuk satu hubungan-hubungan tetap diteruskan pada bentuk kedua hubungan-hubungan dapat dihentikan untuk sebagian atau untuk keseluruhan.

c. Paksaan atau coercion. Satu pihak memaksakan pemecahan kepada pihak lain. Ini bersifat unilateral. Tindakan yang bersifat memaksakan ini atau ancaman untuk menggunakan kekerasan, pada umumnya mengurangi kemungkinan penyelesaian secara damai.

d. Perundingan (negotiation). Dua pihak yang berhadapan merupakan para pengambil keputusan. Pemecahan atas masalah yang dihadapi dilakukan oleh 
mereka berdua. Mereka sepakat tanpa adanya pihak ketiga yang mencampurinya. Kedua belah pihak berupaya untuk saling meyakinkan. Jadi, mereka membuat aturan mereka sendiri dan tidak memecahkannya dengan bertitik tolak dari aturan-aturan yang ada.

e. Mediasi (mediation). Pemecahan dilakukan menurut perantara, mediation. Dalam cara ini ada pihak ketiga yang membantu kedua belah pihak yang berselisih pendapat untuk menemukan kesepakatan. Pihak ketiga ini dapat ditentukan oleh kedua belah pihak yang bersengketa, atau ditunjukkan oleh yang berwenang untuk itu. Baik mediator yang merupakan hasil pilihan kedua pihak, atau karena ditunjuk oleh orang yang mempunyai kekuasaan, kedua pihak yang bersengketa harus setuju bahwa jasa-jasa dari seorang mediator akan digunakan dalam upaya mencari peme-cahan. Dalam masyarakatmasyarakat kecil (paguyuban), bisa saja tokoh-tokh yang berperan sebagai mediator juga berperan sebagai arbitrator dan sebagai hakim.

f. Arbitase. Dua belah pihak yang bersengketa sepakat untuk me-minta perantara pihak ketiga, arbitrator, dan sejak semula telah setuju bahwa mereka akan menerima keputusan dari arbitrator itu.

g. Peradilan, adjudication. Di sini pihak ketiga mempunyai wewenang untuk mencampuri pemecahan masalah, lepas dari keinginan para pihak bersengketa. Pihak ketiga itu juga berhak membuat keputusan dan menegakkan keputusan itu artinya berupaya bahwa keputusan dilaksanakan.

\section{B. METODE PENELITIAN}

Penelitian ini dilaksanakan di Desa Cemba Kecamatan Enrekang Kabupaten Enrekang. Waktu penelitian awal bulan Mei sampai pertengahan Juli 2019. Metode penelitian yang digunakan adalah metode penelitian Kuantitatif yaitu suatu model penelitian yang bersifat induktif, objektif dan ilmiah dimana data yang diperoleh berupa angka-angka (score, nilai) atau pernyataanpernyataan yang dinilai, dan dianalisis dengan analisis statistik.Populasi dalam penelitian ini adalah Seluruh masyarakat Desa Cemba Kecamatan Enrekang Kabupaten Enrekang yang berjumlah (1.875) jiwa. Teknik penarikan sampel yang digunakan adalah rumus Slovin dengan tingkat kesalahan $10 \%$ jadi dalam penelitian ini adalah 95 orang.

Teknik pengumpulan data yang digunakan adalah Observasi, Studi kepustakaan (library research), Kuisioner sedangkan teknik analisis data yang digunakan adalah menggunakan teknik analisis data kuantitatif.

\section{HASIL PENELITIAN DAN PEMBAHASAN}

\section{Kepemimpinan}

Rekapitulasi tanggapan responden tentang kepemimpinan

\begin{tabular}{|c|c|c|}
\hline No & $\begin{array}{c}\text { Tanggapan } \\
\text { Responden }\end{array}$ & Persentase \\
\hline 1 & $\begin{array}{c}\text { Peranan sebagai } \\
\text { motivator }\end{array}$ & $48 \%$ \\
\hline 2 & $\begin{array}{c}\text { Peranan sebagai } \\
\text { fasilitator }\end{array}$ & $49,2 \%$ \\
\hline 3 & $\begin{array}{c}\text { Peranan sebagai } \\
\text { mediator }\end{array}$ & $48 \%$ \\
\hline \multicolumn{2}{|c|}{ Rata-rata persentase } & $\mathbf{4 8 , 4 \%}$ \\
\hline \multicolumn{2}{|c|}{ Sumber Hasil olah data kuesioner 2019} \\
\hline
\end{tabular}

Dari tabel diatas terdapat tiga indikator dalam peran kepemimpinan yang dilakukan oleh peneliti untuk mengukur bagaimana peranan kepemimpinan kepala desa di Desa Cemba Kecematan Enrekang Kabupaten Enrekang. Adapun indikator yang pertama adalah peran sebagai motivator, dari hasil persentase didapatkan $48 \%$ termasuk kategori cukup baik. Untuk indikator yang kedua yakni peran sebagai fasilitator, dari hasil persentase didapatkan 49,2\% termasuk kategori cukup baik. Untuk indikator yang ketiga peran sebagai mediator, dari hasil persentase didapatkan $48 \%$ dikategorikan cukup baik. Hasil rekapitulasi mengenaiperan kepala desa di Desa Cemba KecematanEnrekang Kabupaten Enrekang didapakan $48,8 \%$ yang dikategorikan " Cukup Baik".

\section{Cara menyelesaikan konflik}

Rekapitulasi tanggapan responden mengenai indikator cara menyelesaikan konflik 


\begin{tabular}{|l|l|c|}
\hline No & $\begin{array}{l}\text { Tanggapan } \\
\text { Responden }\end{array}$ & Persentase \\
\hline 1 & Membiarkan saja & $50,4 \%$ \\
\hline 2 & Mengelak & $37,2 \%$ \\
\hline 3 & Paksaan & $38 \% \%$ \\
\hline 4 & Perundingan & $53 \% \%$ \\
\hline 5 & Mediasi & $38 \%$ \\
\hline 6 & Arbitase & $53 \%$ \\
\hline 7 & Peradilan & $40,8 \%$ \\
\hline \multicolumn{2}{|l|}{ Rata-rata persentase } & $44,34 \%$ \\
\hline
\end{tabular}

Tabel diatas terdapat tujuh indikator dalam menyelesaikan konflik yang dilakukan oleh peneliti untuk mengukur cara menyelesaikan konflik di Desa Cemba Kecematan Enrekang Kabupaten Enrekang. Adapun indikator yang pertama adalah membiarkan, dari hasil persentase didapatkan 50,4\% termasuk kategori cukup baik.Untuk indikator yang kedua mengelak, dari hasil presentase didapatkan 37,2\% dikategorikan kurang baik. Untuk indikator yang ketiga paksaan, dari hasil persentase didapatkan 38\% dikategorikan kurang baik, Selanjutnya untuk indikator keempat perundingan, dimana hasil persentase didapatkan $53 \%$ dikategorikan cukup baik. Untuk indikator kelima mediasi dari hasil persentase didapatkan hasil 38\% dkategorikan kurang baik. Untuk indikator arbitase didapatkan hasil persentase 53\% dikategorikan cukup baik, untuk indikator terakhir yaitu peradilan ditemukan hasil persentase sebesar 40,8\% dikategorikan cukup baik. Akumulasi hasil rata-rata persentase dari tujuh item pertanyaan pada indikator diatas, maka didapatkan hasil ratarata persentase, yaitu $44,34 \%$ atau kategori Cukup Baik.

\section{Analisis Tabel Summary}

\begin{tabular}{|l|c|c|c|c|}
\hline $\begin{array}{l}\text { Mod } \\
\mathrm{el}\end{array}$ & $\mathrm{R}$ & $\begin{array}{c}\mathrm{R} \\
\text { Squar } \\
\mathrm{e}\end{array}$ & $\begin{array}{c}\text { Adjusted } \\
\mathrm{R} \text { Square }\end{array}$ & $\begin{array}{c}\text { Std. Error } \\
\text { of the } \\
\text { Estimate }\end{array}$ \\
\hline 1 & $.705^{\mathrm{a}}$ & .497 & .491 & 1.589 \\
\hline
\end{tabular}

Sumber hasil olah data SPSS
Hal ini diperkuat dengan hasil data Model Sumarry, dimana nilai $\mathrm{R}$ Square= 0,497 berarti secara bersama $49,7 \%$ perubahan variabel penyelesaian konflik sengketa tanah $(Y)$ dapat dijelaskan oleh variabel peranan kepala desa $(X)$, atau dengan kata lain pengarh variabel bebas terhadap variabel terikat sebesar 49,7\% sedangkan sisanya 50,3 dipengaruhi oleh factor lain yang tidak masuk dalam kerangka penelitian ini.

\section{SIMPULAN}

Setelah melakukan penelitian selama kurang lebih dua bulan maka penulis menarik kesimpulan untuk menjawab pertanyaan rumusan masalah penelitian. Beberapa kesimpulan yang dapat ditarik dari penelitian ini adalah sebagai berikut:

1. Hasil Analisis olah data frekuensi yang dilakukan, dapat disimpulkan bahwa Peranan Kepala Desa di Desa Cemba Kecamatan Enrekang Kabupaten Enrekang sebesar $48,4 \%$ atau berada dalam kategori Cukup Baik.

2. Analisis olah data frekuensi yang dilakukan diperoleh angka sebesar 44,34 $\%$, hal ini menunjukkan bahwa cara penyelesaian konflik sengketa tanah di Desa Cemba Kecamatan Enrekang Kabupaten Enrekang berada dalam kategori Cukup Baik.berarti perlu ada perhatian pemerintah desa untuk meningkatkan penyelesaian konflik.

upaya-upaya

3. Pengaruh peran kepala desa terhadap penyelesaian konflik di Desa Cemba Kecamatan Enrekang Kabupaten Enrekang dapat dilihat berdasarkannilai $\mathrm{R}$ square dari tabel summary, yaitu berpengaruh sebesar $49.7 \%$ sedangkan $50,3 \%$ dipengaruhi oleh factor-faktor lain yang tidak diteliti.k.

\section{E. REFERENSI}

Ahmad, J. (2015). Metode Penelitian Administrasi Public. Teori dan Aplikasi. Yogyakarta: Penerbit Gava Media.

Arikunto, S. (2013). Prosedur Penelitian: Suatu Pendekatan Praktik. Jakarta: Rineka Cipta.

Kartono Kartini. (2014). Pemimpin dan Kepemimpinan: apakah kepemimpinan 
Abnormal itu. Jakarta: Raja Grafindo Persada.

Nordholt, Schute dan Klinken, Van, G. (2007). Politik lokal di Indonesia. Jakarta: Yayasan Obor Indonesia.

Razak, M. R. R. (2020, March 9). The Effect of Siri's Marriage on Government Administration. Retrieved from osf.io/yx3n7

Razak, M.R.R;Harfiah, S. (Universitas M. S. R. (2018). Partisipasi Masyarakat di Daerah Pegunungan terhadap Perwujudan Good Governance. Akmen Jurnal Ilmiah, 15(3), 476-486.

Rivai, M. (2012). Kepemimpinan dan perilaku organisasi. PT Raja Grafindo Persada.

Robbins, S. P. (2006). Perilaku Organisasi. Jakarta: PT. Indeks Gramedia.

Siswanto, B. (2012). Manajemen Tenaga Kerja Indonesia Pendekatan Administratif dan Operasional. Jakarta: Bumi Aksara.

Soekanto, S. (2002). Teori Peranan. Jakarta: Bumi Aksara.

Soekanto, S. (2012). Sosiologi Suatu Pengantar. Jakarta: Rajawali Pers.

Thoha., M. (2004). Perilaku Organisasi, Konsep Dasar dan Aplikasinya. Jakarta: Raja Grafindo Persada. 